\title{
Ecological and Chemotypic Analysis for Improved Growth and Management of Naturally Occurring Black Cohosh (Actaea racemosa L.) Populations in Western Maryland
}

\author{
Amanda Vickers ${ }^{1,2}$, Sunshine L. Brosi ${ }^{*}$, James Howell ${ }^{3}$, Bhavneet Kaur ${ }^{4,5}$, \\ David Puthoff ${ }^{1}$, Edward Eisenstein ${ }^{4,6^{*}}$ \\ ${ }^{1}$ Frostburg State University, Frostburg, USA \\ ${ }^{2}$ US Botanical Safety Lab, Candler, USA \\ ${ }^{3}$ Allegany College of Maryland, Cumberland, USA \\ ${ }^{4}$ Institute for Bioscience and Biotechnology Research, Rockville, USA \\ ${ }^{5}$ Sustainable Agricultural Systems Laboratory, Beltsville Agricultural Research Center, USDA-ARS, \\ Beltsville, USA \\ ${ }^{6}$ Fischell Department of Bioengineering, University of Maryland, Rockville, USA \\ Email: " slbrosi@frostburg.edu, "eisenstein@umd.edu
}

Received 15 October 2015; accepted 27 December 2015; published 30 December 2015

Copyright (C) 2015 by authors and Scientific Research Publishing Inc.

This work is licensed under the Creative Commons Attribution International License (CC BY).

http://creativecommons.org/licenses/by/4.0/

(c) (i) Open Access

\section{Abstract}

Black cohosh (Actaea racemosa $\mathrm{L}$.) is a perennial herb native to deciduous woodlands in eastern North America with an extensive history of traditional use, most commonly for rheumatoid arthritis and female reproductive issues. Modern clinical research has maintained this herb's relevance into the $21^{\text {st }}$ century with a majority of authentic black cohosh raw material still harvested from naturally occurring populations in Appalachian woodlands for use in botanical supplements. Increased use and interest in black cohosh have led to increased wild harvesting, reports of adulteration, and stress on this important natural resource. In an effort to study this significant medicinal plant as part of an ecosystem, and to understand factors that would contribute to the more effective growth and maintenance of black cohosh, key chemical, physiological, and ecological aspects of two occurring populations in western Maryland were surveyed. Rhizomes were harvested from six populations of naturally occurring black cohosh in two state forests located in the Allegheny Plateau and Ridge and Valley physiogeographic provinces of Maryland. The concentrations of

${ }^{*}$ Corresponding authors.

How to cite this paper: Vickers, A., Brosi, S.L., Howell, J., Kaur, B., Puthoff, D. and Eisenstein, E. (2015) Ecological and Chemotypic Analysis for Improved Growth and Management of Naturally Occurring Black Cohosh (Actaea racemosa L.) Populations in Western Maryland. American Journal of Plant Sciences, 6, 3272-3281. http://dx.doi.org/10.4236/ajps.2015.619319 
five medicinal compounds found in black cohosh extracts, actein, 23-epi-26-deoxyactein, cafeic acid, ferulicacid, and $N$-methylserotonin, were compared with plant reproductive status as well as accompanying overstory and under story species, soil moisture, and soil $\mathrm{pH}$ at each site. Compound levels showed a complex dependence on physiography but were independent of reproductive state. The findings provide clues to guide efforts at effective growth and management of wild populations of black cohosh and other threatened medicinal plants.

\section{Keywords}

\section{Actaea racemosa, Rhizome, Natural Products, Physiographic Province, Reproductive State}

\section{Introduction}

Wild harvesting of native black cohosh (Actaea racemosa L., Ranunculaceae (formerly Cimicifuga racemosa (L.) Nutt.)) rhizomes for herbal products is an important source of income for many small-scale harvesters, consolidators, and finished product manufacturers in the Appalachian region. Black cohosh is a relatively slow-growing perennial herb and root medicine that has been used for muscle spasms, rheumatism, premenstrual symptoms, and as a preparatory for childbirth [1] [2]. Recently, demand for black cohosh as a remedy for hot flashes increased following concerns over increased incidences of estrogenic cancers in women undergoing Hormone Replacement Therapy (HRT) for menopausal symptoms. Consequently, black cohosh has remained in the top forty herbs of commerce based on annual sales [3]-[5]. Black cohosh ranked $10^{\text {th }}$ in the top-selling herbal dietary supplement in the US in 2008, with total sales valuing more than \$8M [6]. A 2001 survey of buyers in North Carolina found that of the $1675 \mathrm{~kg}$ sold to buyers, 96\% was wild harvested from Appalachian woodlands [7].

The increased demand of black cohosh has led to an increase in wild harvesting. Accordingly, several Actaea species are of conservation concern with various designations for rank (1: critically imperiled, 2: imperiled, 3: vulnerable, 4: apparently secure, 5: secure) across political boundaries (Global, National, and State) and status (Endangered and Threatened) within the United States and across the political boundaries of Federal and State [8]. Globally and in the US A. racemosa is considered apparently secure (G4, N4) but imperiled in Canada (N2) and in Ontairo, the only province in which it occurs (S2) [8]. Within the US the species is ranked as possibly extirpated (SH) in Iowa and Michigan; imperiled (S1) and state endangered in Illinois and Massachusetts. Black cohosh is also ranked as S1 in Mississippi and vulnerable (S3) in Indiana (S3) [8]. A. racemosa has been identified as a priority for further study by the US Fish and Wildlife Service, and has been known to decline in recent years [9]. Small et al. suggest that populations may be able to regenerate from a moderately intense harvest (33\%), but those that experienced an intense (66\%) harvest showed no sign of recovery after one year, providing quantitative evidence that black cohosh populations are succeptible if over-harvested, and that relatively long recovery periods would be required for population renewal [10]. This susceptibility is exacerbated by competition for habitat from logging, coal, and natural gas industries, development pressures from an expanding human population, climate change, and an increased demand for raw material. As a precautionary response some states, such as North Carolina, place black cohosh under more restrictive harvest guidelines than other more abundant or more quickly regenerating medicinal plants.

Concomitant with increased demand, concerns have been raised with respect to widespread mislabeling and unintentional or deliberate adulteration of dietary supplements labeled as black cohosh, in part due to the availability of closely related species with similar constituent profiles [11]. Asian species in the Actaea genus include A. heracleifolia (Kom.) J. Compton, A. dahurica (Turczaninow ex Fischer \& CA Meyer), A. foetida L., A. cimicifuga L. and A. asiatica Hara. Although the range of these species does not overlap with black cohosh in the wild, unfortunately, they have been documented as adulterants in commercial "black cohosh" products in the US [12]. In eastern North America, the genus Actaea includes a number of closely related species with overlapping ranges A. podocarpa DC, A. pachypoda Elliott, A. rubifolia (Kearney) Kartesz, and A. rubra (Aiton) Willd. Many of these species are exceptionally difficult to distinguish from black cohosh in the field except by reproductive structures. Many robust methods of chemical identity verification have been developed, but are typically employed on larger lots of material, compounded from many small harvests [13]-[15]. 
Historically, other slow-growing mesic cove species in this region have also been highly valued for their roots, e.g. American ginseng (Panax quinquefolius L.) [16] and goldenseal (Hydrastis canadensis L.) [17], with many naturally occurring populations having been completely wiped out in the $19^{\text {th }}$ and $20^{\text {th }}$ centuries before being fully documented or thoroughly characterized in situ. Due to the combined threat of land use change and accidental harvest, proper identification of black cohosh in the field and in the marketplace is essential not only to quality control of the target species, but also to the conservation of less common Actaea species, especially A. podocarpa and A. rubifolia. Thus, a number of alternatives have been considered for the growth and maintenance of black cohosh to provide authentic plant material for botanical supplements.

Very little is known about the complex relationship between the secondary metabolites that constitute the medicinal extracts of black cohosh, the physiology of the plant and the interactions of the plant with other environmental variables. This study was undertaken to examine the chemotypic variations among six populations of black cohosh in two Maryland state forests, and aims to examine relationships between five signature natural products found in botanical extracts with ecological and physiological attributes of the plants. Interestingly, medicinal natural products correlated most closely with physiographic parameters, and not with rhizome size or reproductive status of plants. These findings will assist agroforestry efforts for enhancing the growth and maintenance of black cohosh to preserve natural populations.

\section{Materials and Methods}

A collection of 105 black cohosh rhizomes was harvested from six naturally occurring populations in two state forests in Maryland. These rhizomes were subjected to standard post-harvest drying, grinding and extraction with $100 \%$ methanol.

\subsection{Study Area}

The study area consisted of six sites each with both raceme-bearing and vegetative taxa in Savage River State Forest (39.68, -79.21) in Garrett County, MD (Allegheny Plateau Physiographic Province) and in Green Ridge State Forest $(39.67,-78.46)$ in eastern Allegheny County, MD (Ridge and Valley Physiographic Province). Savage River State Forest has one of the highest annual precipitations of the state (47 inches) while the rain shadow area of Green Ridge State Forest is the state's driest at just 36 inches [18]. The average acidity and moisture in the Savage River sites was found to be $\mathrm{pH} 6.8$ and 28.7\%, compared to $\mathrm{pH} 7$ and $0.7 \%$ moisture in Green Ridge. Savage River sites maintained a dense Quercus L. Carya Nutt. And Acer L. association whereas dominant overstory species at Green Ridge State Forest were Prunus serrotina Ehrh and Fraxinus americana L. (Table 1). A total of 60 rhizomes (30 in year 1 and 30 in year 2) were harvested from four sites in Savage River State Forest, and 45 rhizomes (19 in year 1, 26 in year 2) were harvested from two sites in Green Ridge State Forest.

\subsection{Plant Material}

All plant material was harvested during the period of July 30 to August 11, 2010 and in the same period in 2011. At the time of harvest, all raceme-bearing plants were post-flowering, bearing racemes with either fruit or nonfertile flower remnants. Belowground and aboveground portions were separated at the first growth scar on each rachis during harvest. All plant material was bagged in paper and transported on ice to the laboratory for immediate cleaning, weighing and drying at $50^{\circ} \mathrm{C}$ to constant weight. Drying times were from 24 to 72 hours due to variation in size. Dry masses of aboveground and belowground portions were recorded and rhizomes stored at $-20^{\circ} \mathrm{C}$ until grinding. Vouchers were deposited at The North Carolina Arboretum Germplasm Repository (NCAM, AV201108001-AV201108005).

Dried belowground portions were pounded and ground using a Wiley Mini-Mill 3383-L10 through a one millimeter mesh screen. One gram of ground plant material was then weighed and recorded to one-milligram accuracy. Three milliliters of $100 \%$ methanol were added to the powdered plant material, which was then vortexed and sonicated at room temperature for ten minutes. The samples were centrifuged at $21,500 \times \mathrm{g}$ for five minutes and the supernatant collected. Three additional milliliters of methanol were then added to the residual plant material and the entire protocol was repeated for a total of three extractions. The volume of the combined supernatants was brought to $10 \mathrm{~mL}$ with methanol. Each sample was filtered using $0.2 \mu \mathrm{m}$ Acrodisc PTFE syringe filters into the appropriate chromatography vials. 
Table 1. Plant species identified in study areas.

\begin{tabular}{|c|c|c|c|c|c|}
\hline \multicolumn{4}{|c|}{ Savage River State Forest (Allegheny Plateau) } & \multicolumn{2}{|c|}{$\begin{array}{l}\text { Green Ridge State Forest } \\
\text { (Ridge and Valley) }\end{array}$} \\
\hline Site 1 & Site 2 & Site 3 & Site 4 & Site 5 & Site 6 \\
\hline \multicolumn{6}{|c|}{ Overstory species } \\
\hline & Quercus rubra & Acer saccharum & Acer saccharum & Prunus serotina & Prunus serotina \\
\hline & Quercus alba & Acer pensylvanicum & Hammamelis virginiana & Sassafras albidum & Sassafras albidum \\
\hline & Carya glabra & & Acer pensylvanicum & & Fraxinus americand \\
\hline & Acer saccharum & & Quercus rubra & & \\
\hline & Magnolia acuminata & & & & \\
\hline & Tilia americana & & & & \\
\hline \multicolumn{6}{|c|}{ Understory species } \\
\hline Asarum canadense & Rubus spp. & Arctium lappa & Rubus spp. & $\begin{array}{l}\text { Microstegium } \\
\text { vimineum }\end{array}$ & Cirsium discolor \\
\hline \multirow[t]{10}{*}{ Viola spp. } & Impatiens capensis & $\begin{array}{l}\text { Desmodium } \\
\text { nudiflorum }\end{array}$ & Osmorhiza claytonii & Vitis spp. & Botrychium spp. \\
\hline & Viola spp. & Alliaria petiolata & $\begin{array}{l}\text { Polystichum } \\
\text { acrostichoides }\end{array}$ & Smilax spp. & Dioscorea villosa \\
\hline & Dioscorea villosa & Adiantum pedatum & Sedum ternatum & & Cercis canadensis \\
\hline & $\begin{array}{l}\text { Polystichum } \\
\text { acrostichoides }\end{array}$ & Smilax spp. & Desmodium spp. & & \\
\hline & $\begin{array}{l}\text { Rhododendron } \\
\text { maximum }\end{array}$ & & Tussilago farfara & & \\
\hline & $\begin{array}{l}\text { Parthenocissus } \\
\text { quinquefolia }\end{array}$ & & $\begin{array}{c}\text { Caulophyllum } \\
\text { thalictroides }\end{array}$ & & \\
\hline & Osmorhiza claytonii & & Asarum canadense & & \\
\hline & Dryopteris spp. & & Sanguinaria canadensis & & \\
\hline & Polygonatum biflorum & & $\begin{array}{l}\text { Hepatica nobilis } \\
\text { var. acuta }\end{array}$ & & \\
\hline & & & Actaea pachypoda & & \\
\hline
\end{tabular}

The efficiency of the extraction method was evaluated by analyzing the three successive fractions recovered from each gram of ground material. The analysis suggested that the extraction was not exhaustive and that further rounds of solvent extraction would have continued to yield more of all five compounds, following a trend of exponential decay. As such, estimations of concentration in rhizome mass herein must be considered estimations of extracted mass per gram of rhizome.

\subsection{Analytical Methods}

Preliminary HPLC analysis of plant extracts utilized a Dionex ICS-3000 HPLC unit equipped with a Varian 380-LC ELSD detector and Chromeleon (Dionex Corp.) analytical software. The column used was an Ace $100 \AA$ Ultra-Inert Base Deactivated Analytical C18-AR, size $4.6 \times 250$ mm from Mac Mod Analytical in Chadds Ford, PA and the separation methods was adapted from Li et al. [19]. This approach was suitable for qualitatively assessing the presence of signature metabolites in the harvested collection but was inadequate to unequivocally identify trace metabolites and their concentrations. Therefore, UPLC-MS was employed using a Waters Acquity Ultra Performance Liquid Chromatography/LCT Premier XE TOF Mass spectrometer system (Waters Corporation, Milford, MA) with a Waters C18 BEH $1.7 \mu \mathrm{m}, 2.1 \times 50 \mathrm{~mm}$ column [20].

Screw neck $(12 \times 32)$ glass vials with bonded preslit PTFE/Silicone septa (catalog \#186000327c, Waters Corporation, Milford, MA) were used for loading samples (filtered through $0.45 \mu \mathrm{m}$ filter, $2 \mu \mathrm{L}$ volume) each of 
which was injected in triplicate. The hydrophobic stationary phase used was a C18 BEH $1.7 \mu \mathrm{m}, 2.1 \times 50 \mathrm{~mm}$ column maintained at $40^{\circ} \mathrm{C}$. A binary solvent system consisting of $0.1 \%$ aqueous formic acid (solvent $\mathrm{A}$ ) and acetonitrile-methanol (solvent $\mathrm{B}$ in a 7:3 ratio) was used as the mobile phase. An 8 minute solvent gradient was employed for elution of all compounds comprising of $90 \% \mathrm{~A} / 10 \%$ B for $0-0.2$ min; 10\%A/90\% B for 0.2 - 6.5 min (concave gradient; Waters curve type 7); 10\%A/90\%B for 6.5 - 7.0 min and 90\%A/10\% B from 7.0 - 8.0 min with a flow rate of $0.450 \mathrm{~mL} / \mathrm{min}$. Photodiode array (PDA) detector recorded the spectra from 190 - 400 nm.

The eluate from UPLC was conveyed in line to an LCT Premier XE TOF Mass spectrometer system (Waters Corporation, Milford, MA) and Mass spectra were recorded. The mass spectrometer was run in both the positive and negative ion modes but electrospray ionization in positive mode enabled good ionization for all compounds under study. The $\mathrm{W}$-optics mode was used for increased resolution. The capillary voltage was set to $3000 \mathrm{~V}$ and cone voltage was $30 \mathrm{~V}$. Nitrogen was used for both the nebulizer and in desolvation. The desolvation and cone gas flows were $350 \mathrm{~L} / \mathrm{h}$ and $10 \mathrm{~L} / \mathrm{h}$, respectively. The desolvation temperature was $350^{\circ} \mathrm{C}$ and source temperature was $120^{\circ} \mathrm{C}$. For the dynamic range enhancement (DRE) lockmass, $200 \mathrm{pg} / \mathrm{ml}$ solution of leucine-enkephalin in acetonitrile: water $(1: 1)$ containing $0.1 \%$ formic acid was infused using a secondary probe. Instrument control and data acquisition was done by MassLynx software and mass spectra were recorded from 90 - 1100 Da. Quantification of different secondary metabolites was done using QuanLynx module.

To make standard curves for each of five standards, actein, 23-epi-26-deoxyactein, ferulic acid, caffeic acid, and $N$-methylserotonin, the range of linearity was established by best-fit regression $\left(\mathrm{R}^{2} \geq 0.99\right)[21]$. Extracts were diluted in $0.2 \mu \mathrm{m}$ filtered HPLC grade methanol to be within the linear range of the standard curve of each compound being quantified. The limit of detection (LOD) was determined as the concentration resulting in a peak height that was three times the baseline noise level $(\mathrm{S} / \mathrm{N}=3)$. Precision on intra-day and inter-day runs was determined by assay of standard solutions at seven different concentrations in a single day and on five different days respectively [21]. Stability was tested by analysis of sample solutions stored at $4{ }^{\circ} \mathrm{C}$ for 0 , 24 , and 48 hours.

\subsection{Statistical Analysis}

Normality was assessed by Kolmogorov-Smirnov and data was found to be non-normal with $p$-values close to zero. Log transformations failed to normalize data, so the Mann-Whitney nonparametric test for comparison of medians was used to assess differences between groups. For ferulic acid and caffeic acid, values that were below the range of detection were assigned a value of one half the minimum value [22].

\section{Results}

\subsection{Analysis of Black Cohosh Rhizomes and Signature Metabolites}

Although the size of black cohosh rhizomes varied according to both physiographic region $(p=0.033)$, year $(p=$ $0.025)$, and reproductive state $(p<0.01)$, the most significant difference in size was related to physiographic region. As can be seen in Table 2, the difference in average mass between physiographic regions was the most significant with the average mass in the Allegheny Plateau (57.7 g) more than twice (three times) that of the Ridge and Valley Province (18.1 g). Difference in rhizome weight from year one (53.9 g) to year two showed a $53 \%$ decrease in mass of the average harvested rhizome. The average mass of rhizomes from raceme-bearing plants (48.8 g) showed a 43\% increase over the average mass of rhizomes from vegetative only plants (33.8 g). The wet and dry weights of aboveground portions and belowground portions were positively correlated $\left(\mathrm{R}^{2}=\right.$ 0.52 and 0.49 respectively).

Initial analysis of black cohosh rhizome extracts utilized HLPC with ELS detection to qualitatively analyze with five signature metabolites: actein, 23-epi-26-deoxyactein, ferulic acid, caffeic acid and $N$-methylserotonin. As can be seen in Figure 1, this approach enabled the identification of actein and 23-epi-26-deoxyactein in extracts of black cohosh rhizomes, but with the close retention time of these species, the ELSD approach was unable to provide an accurate analysis of their concentrations. Therefore, UPLC combined with ESI-TOF-MS was employed for quantitative analysis of black cohosh metabolites [20]. As can be seen in Figure 2, the difference in the retention times of actein and 23-epi-26-deoxyactein are small, but enable their unambiguous assignment using ESI-TOF-MS. The 2 Dalton difference as seen in the extracted ion chromatograms is sufficient to allow for estimates of these compounds in rhizome samples. The amounts of the five signature compounds in the biological samples collected in this study are presented in Table 3. 


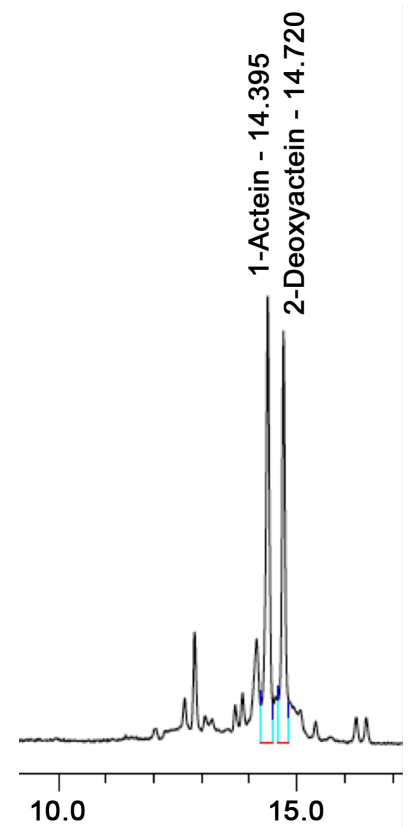

Figure 1. Identification of actein and 23-epi-26-deoxyactein in black cohosh rhizomes using HPLC retention time with evaporative light scattering detection relative to standard compounds. Representative separation of a black cohosh rhizome extract on a Varian 380 HPLC with ELS detection demonstrates the presence of actein and 23-epi-26-deoxyactein but the inability to achieve baseline separation posed challenges for this method to yield quantitative results of compound levels.

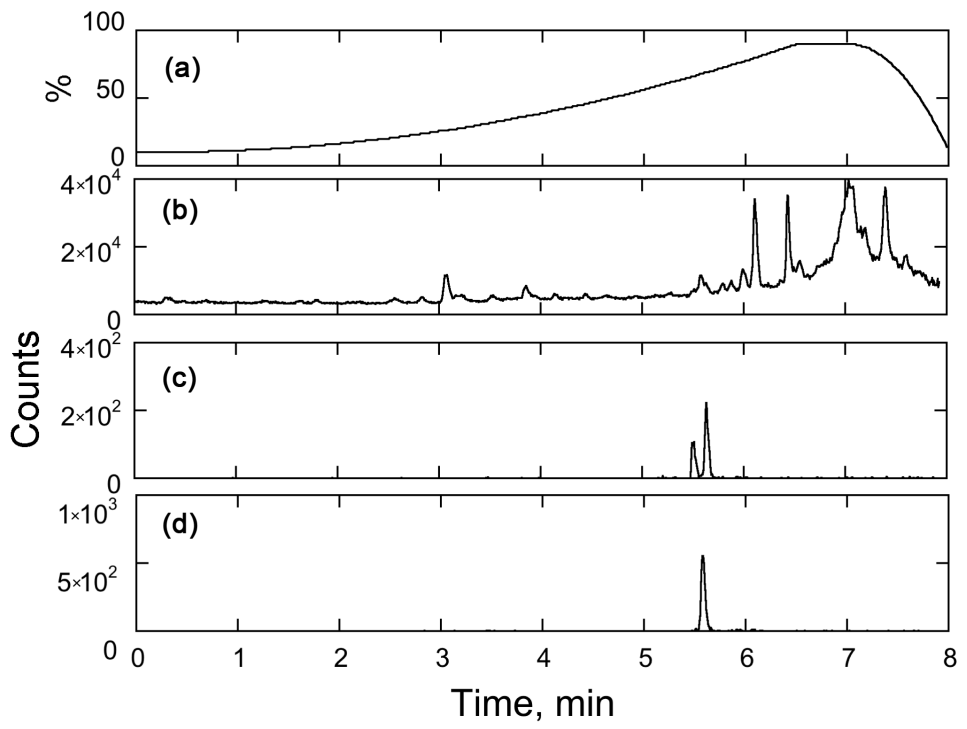

Figure 2. Identification of actein and 23-epi-26-deoxyactein in black cohosh rhizomes using UPLC-ESI-TOF-MS relative to standard compounds. (a) Solvent gradient; (b) Total ion chromatogram; and overlapping elution times of (c) 23-epi-26deoxyactein and (d) R- and S-actein (dehydrated) standard compounds can be resolved easily by TOF-MS.

Table 2. Characteristics of black cohosh rhizomes from the study areas*.

\begin{tabular}{lcccccc} 
& 2010 & 2011 & Savage River & Green Ridge & Plant with raceme & Plant without raceme \\
\hline \multirow{2}{*}{ Mass (g) } & 53.9 & 30 & 57.7 & 18.1 & 48.8 & 33.8 \\
& & $(0.025)$ & \multicolumn{2}{c}{$(0.033)$} & & $(<0.01)$ \\
\hline
\end{tabular}

"Mean mass presented with P values in parenthesis to indicate the significance level of the difference in weight. 
Table 3. Black cohosh signature metabolites in rhizomes isolated from study areas*.

\begin{tabular}{|c|c|c|c|c|c|c|}
\hline & \multirow{2}{*}{$\begin{array}{c}\text { Savage River } \\
2010\end{array}$} & \multirow{2}{*}{$\begin{array}{c}\text { Green Ridge } \\
2011\end{array}$} & \multicolumn{2}{|c|}{ Plants with raceme } & \multicolumn{2}{|c|}{ Plants without raceme } \\
\hline & & & 2010 & 2011 & 2010 & 2011 \\
\hline \multirow[t]{2}{*}{ Actein } & 777.4 & 585.3 & 934.0 & 454.1 & 988.8 & 483.7 \\
\hline & \multicolumn{2}{|c|}{$(0.019)$} & \multicolumn{2}{|c|}{$(0.002)$} & \multicolumn{2}{|c|}{$(0.004)$} \\
\hline \multirow[t]{2}{*}{ 23-epi-26-deoxyactein } & 187.8 & 131.2 & 210.6 & 108.1 & 238.0 & 117.3 \\
\hline & \multicolumn{2}{|c|}{$(<0.001)$} & \multicolumn{2}{|c|}{$(0.001)$} & \multicolumn{2}{|c|}{$(0.003)$} \\
\hline \multirow[t]{2}{*}{ Ferulic Acid } & 46.07 & 41.82 & 53.17 & 34.37 & 57.96 & 34.74 \\
\hline & \multicolumn{2}{|c|}{$(0.036)$} & \multicolumn{2}{|c|}{$(0.141)$} & \multicolumn{2}{|c|}{$(0.037)$} \\
\hline \multirow[t]{2}{*}{ Caffeic Acid } & 6.29 & 6.90 & 6.20 & 3.87 & 4.03 & 2.75 \\
\hline & \multicolumn{2}{|c|}{$(0.04)$} & \multicolumn{2}{|c|}{$(0.072)$} & \multicolumn{2}{|c|}{$(0.317)$} \\
\hline \multirow[t]{2}{*}{$N$-methylserotonin } & 16.40 & 15.63 & 16.35 & 12.05 & 14.39 & 19.77 \\
\hline & \multicolumn{2}{|c|}{$(0.862)$} & \multicolumn{2}{|c|}{$(0.022)$} & \multicolumn{2}{|c|}{$(0.963)$} \\
\hline
\end{tabular}

"Masses of constituents are given in micrograms per gram of extracted raw material. P-values in parenthesis indicate the significance in the difference in these measurements.

\subsection{Correlation of Rhizome Constituent Concentration on Physiographic Region, Annual Variation and Reproductive State of Black Cohosh}

It was of interest to relate the quantitative levels of black cohosh signature metabolites with ecological and physiological information to provide clues that could guide the growth and management of this important Appalachian medicinal plant. Mann-Whitney rank sum was used to compare the concentration of the five constituent signature compounds ( $\mu$ g compound per gram dried rhizome) across physiographic regions (Table 3). A direct comparison of means shows that on average, rhizomes from the Allegheny plateau contain 33\% more actein (777.4 vs. $585.3 \mu \mathrm{g}), 43 \%$ more 23-epi-26-deoxyactein (187.8 vs $131.2 \mu \mathrm{g}$ ), and $10 \%$ more ferulic acid (46.07 vs $41.82 \mu \mathrm{g}$ ) than rhizomes from the Ridge and Valley provinces. Comparison of means shows that Allegheny rhizomes also contained 5\% more $N$-methylserotonin than those in the other provinces, though the difference was not significant. Caffeic acid was the only compound that was found in $10 \%$ greater amounts (6.90 vs. 6.29 $\mu \mathrm{g})$ in rhizomes from the Ridge and Valley Province compared with those from the Allegheny Plateau.

Significant annual difference was defined as a difference that was greater than that expected by random chance. Variation between the two years collected was found to be significant for actein $(p<0.001)$, 23-epi-26deoxyactein $(<0.001)$, ferulic acid $(p=0.011)$ and caffeic acid $(p=0.037)$ when raceme-bearing and vegetative plants were grouped. Considering only the raceme-bearing individuals, variation between the two years collected was significant for actein $(p=0.002)$, 23-epi-26-deoxyactein $(p=0.001)$ and $N$-methyl-serotonin $(p=$ $0.022)$.Within only the vegetative group, the annual variation was significant for actein $(p=0.004)$, 23-epi-26-deoxyactein $(p=0.003)$ and ferulic acid $(p=0.037)$.

Overall, reproductive state did not appear to be correlated with rhizome size or concentration of target compounds. For data pooled from both years, no compounds showed a significant change between the racemebearing and vegetative groups ( $p=0.195$ to 0.685 ). $N$-methylserotonin did show a significant difference between these groups in year two, but no significant difference was seen either in year one, or overall. Plants in different reproductive states also did not show a significant difference in the total yield of any compound per rhizome mass as calculated by dry rhizome mass times the extracted concentration of each compound per gram of dry rhizome tissue.

\subsection{Rhizome Size and Constituent Concentration Are Weakly Correlated}

Since wild-harvesters frequently seek the largest black cohosh rhizomes for sale to buyers, it was of interest to see whether constituent concentration correlated with rhizome size. Interestingly, the concentrations of actein, 23-epi-26-deoxyactein, ferulic, and caffeic acids, and $N$-methylserotonin did not appear to be strongly correlated 
with rhizome mass $\left(\mathrm{R}^{2}=0.284,0.199,0.066\right.$ and 0.061 , and 0.018 respectively). Additionally, no compound was seen to decrease in concentration with increasing rhizome mass.

\section{Discussion}

Complementary studies on the ecological, physiological and chemotypic analysis of medicinal plants will increase our understanding of these species as both a natural resource and a source of medically active compounds, and will provide important information that could be used to guide effective growth and management of wild populations. Our initial study on naturally occurring variations in chemical constituents of wild-harvested black cohosh from two Maryland state forests provides a starting point for our understanding of the growth and management of this important natural resource. Interestingly, different levels of medicinal natural products were found in both physiographic regions and showed a complex relationship with physiographic parameters. Strikingly, little difference was seen between plants in different reproductive states. The most significant difference was seen in rhizomes harvested from plants from Savage River State Forest, (Allegheny Plateau Physiographic Province) which generally exhibited larger masses, and higher levels of actein, 23-epi-26-deoxyactein and ferulic acid.

There is evidence that levels of certain triterpene glycosides, the compounds that typically are used to standardize commercial black cohosh extracts, vary across particular tissues of black cohosh with up to ten times higher concentrations in tissues of the early flowering raceme [23]. The mechanism of action of these compounds in humans and in plants has been extensively studied though remains elusive, but in plants it is thought that some of the terpenoid compounds may play a role in attracting pollinators [24]. It is unknown, however, if selection of plants with active reproductive features would affect the concentrations of active constituents in the rhizome.

Interestingly, rhizomes from the drier Ridge and Valley province were significantly smaller than those from the Allegheny Plateau, yet showed an increase in one medicinal compound: caffeic acid. Previous research has shown that the activity of phenylalanine ammonialyase (PAL), the enzyme catalyzing the conversion of phenylalanine into cinnamic acid, increases in times of plant stress, such as low water or nutrient availability, or pathogen invasion [25]. As cinnamic acid is the first intermediate in the secondary metabolic pathway for caffeic acid (and ferulic and isoferulic acid), it is conceivable that under stressful conditions an increase in PAL activity could accelerate the production of any or all of these compounds. Correspondingly, caffeic and ferulic acid are allelopathic inhibitors in some plants, which release them into the soil to reduce competition from surrounding plants. Although it is unknown whether black cohosh utilizes this tactic as a defense response during stress, mild drought-induced stress could be used in agroforestry situations to enhance specific metabolite levels in this and possibly other medicinal plants.

Several simple approaches may be gleaned from these findings for advancing conservation and agroforestry efforts involving black cohosh growth and maintenance. First, since there is little difference between medicinally active natural products in plants with or without racemes, it would be prudent to focus wild harvest efforts on raceme-bearing plants to avoid accidental collection of related species that are difficult to distinguish except by reproductive structures. Furthermore, harvest could be restricted to plants that have already dropped seeds from racemes in order to preserve the natural distribution of germplasm. Finally, cultivation and/or harvest efforts could focus on areas with soil at slightly acidic $\mathrm{pH}$ values and at high moisture levels. These conditions correlate with increased rhizome mass, allowing for larger harvest without the need to sacrifice more plants for collection yield.

\section{Acknowledgements}

United States Department of Agriculture Grant USDA 2008-38922-19537 and the Appalachian Center for Ethnobotanical Studies (ACES) provided support for this project. Close collaboration with Maryland Department of Natural Resources forest managers Mark Beals, John Denning and Wade Dorsey, and heritage ecologists Dan Feller and Ed Thompson is gratefully acknowledged. Student involvement included: Frostburg State University ethnobotany undergraduate students Morgan Bauer, Joy Riddell, and Susan Snow; applied ecology and conservation biology graduate student Robert Kutchman; and Allegany College of Maryland undergraduate students Erica Diehl and Devin George. Thanks to Marie D. Knight for HPLC data. Mimi Hernandez, BebeElrick, Sarah Schober and Joe-Ann McCoy are thanked for providing additional support. 


\section{References}

[1] Moerman, D.E. (2009) Native American Medicinal Plants: An Ethnobotanical Dictionary. Timber Press, Portland.

[2] Hamel, P. and Chiltoskey, M. (1975) Cherokee Plants and Their Uses-A 400 Year History. Herald Publishing Company, Sylva.

[3] Beral, V. (2003) Breast Cancer and Hormone-Replacement Therapy in the Million Women Study. Lancet, 362, 419427. http://dx.doi.org/10.1016/S0140-6736(03)14065-2

[4] Blumenthal, M. (2000) Herb Sales Down 3\% in Mass Market Retail Stores-Sales in Natural Food Stores Still Growing, but at Lower Rate. Herbalgram, 49, 68.

[5] Lindstrom, A., Ooyen, C., Lynch, M., and Blumenthal, M. (2013) Herb Supplement Sales Increase 5.5\% in 2012: Herbal Supplement Sales Rise for 9th Consecutive Year; Turmeric Sales Jump 40\% in Natural Channel. HerbalGram, 99, 60-65.

[6] Cavaliere, C., Rea, P., Lynch, M. and Blumenthal, M. (2009) Herbal Supplement Sales Experience Slight Increase in 2008. HerbalGram, 82, 58-61.

[7] Greenfield, J. and Davis, J.M. (2003) Collection to Commerce: Western North Carolina Non-Timber Forest Products and Their Markets. 2003 Report. North Carolina State University, Raleigh. http://catawba.ces.ncsu.edu/fletcher/programs/herbs/pdf/ntfpfinal17.pdf

[8] NatureServe (2015) NatureServe Explorer: An Online Encyclopedia of Life [Web Application]. Version 7.1. NatureServe, Arlington. http://www.natureserve.org/explorer

[9] University of Maryland Sustainable Development and Conservation Biology Problem Solving Group (1999) Review of Four Species for Potential Listing on the Convention on International Trade in Endangered Species, Appendix II.

[10] Small, C., Chamberlain, J. and Mathews, D. (2011) Recovery of Black Cohosh (Actaea racemosa L.) Following Experimental Harvests. The American Midland Naturalist, 166, 339-348. http://dx.doi.org/10.1674/0003-0031-166.2.339

[11] Foster, S. (2013) Exploring the Peripatetic Maze of Black Cohosh Adulteration: A Review of the Nomenclature, Distribution, Chemistry, Market Status, Analytical Methods and Safety. Herbalgram, 98, 32-51.

[12] Jiang, B., Yang, H., Nuntanakorn, P., Balick, M., Kronenberg, F. and Kennelly, E. (2005) The Value of Plant Collections in Ethnopharmacology: A Case Study of an 85-Year-Old Black Cohosh (Actaea racemosa L.) Sample. Journal of Ethnopharmacology, 96, 521-528. http://dx.doi.org/10.1016/j.jep.2004.09.049

[13] Upton, R., Ed. (2002) Black Cohosh Rhizome, Actaea racemosa L., syn. Cimicifuga racemosa (L.) Nutt.: Standards of Analysis, Quality Control, and Therapeutics. American Herbal Pharmacopoeia, Santa Cruz.

[14] Jiang, B., Ma, C., Motley, T., Kronenberg, F. and Kennelly, E. (2011) Phytochemical Fingerprinting to Thwart Black Cohosh Adulteration: A 15 Actaea Species Analysis. Phytochemical Analysis, 22, 339-351. http://dx.doi.org/10.1002/pca.1285

[15] Ma, C., Kavalier, A., Jiang, B. and Kennelly, E. (2011) Metabolic Profiling of Actaea Species Extracts Using High Performance Liquid Chromatography Coupled with Electrospray Ionization Time-of-Flight Mass Spectrometry. Journal of Chromatography A, 1218, 1461-1476. http://dx.doi.org/10.1016/j.chroma.2011.01.033

[16] Case, M., Flinn, K., Jancaitis, J., Alley, A. and Paxton, A. 2007. Declining abundance of American ginseng (Panax quinquefolius L.) documented by herbarium specimens. Biological Conservation 134(1): 22-30. http://dx.doi.org/10.1016/j.biocon.2006.07.018

[17] Mulligan, M. and Gorchov, D. (2004) Population Loss of Goldenseal, Hydrastis canadensis L. (Ranunculaceae) in Ohio. Journal of the Torrey Botanical Society, 131, 305-310. http://dx.doi.org/10.2307/4126936

[18] Perdue, J.L. (2011) Maryland Comprehensive State Forest Assessment. Maryland Department of Natural Resources, Forest Service, Annapolis.

[19] Li, W., Sun, Y., Liang, W., Fitzloff, J. and van Breemen, R. (2003) Identification of Caffeic Acid Derivatives in Actaea racemosa (Cimicifuga racemosa, Black Cohosh) by Liquid Chromatography/Tandem Mass Spectrometry. Rapid Communications in Mass Spectrometry, 17, 978-982. http://dx.doi.org/10.1002/rcm.1008

[20] Spiering, M. Kaur, B., Parsons, J.F. and Eisenstein, E. (2013) Systems Approaches to Unraveling Plant Metabolism: Identifying Biosynthetic Genes of Secondary Metabolic Pathways. Methods in Molecular Biology, 1083, 253-273. http://dx.doi.org/10.1007/978-1-62703-661-0 15

[21] Avula, B., Wang, Y., Smillie, T. and Khan, I. (2009) Quantitative Determination of Triterpenoids and Formononentin in Rhizomes of Black Cohosh (Actaea racemosa) and Dietary Supplements by Using UPLC-UV/ELS Detection and Identification by UPLC-MS. Planta Medica, 75, 381-386. http://dx.doi.org/10.1055/s-0028-1088384

[22] Reimann, C. and Filzmoser, P. (1999) Normal and Lognormal Data Distribution in Geochemistry: Death of a Myth. Consequences for the Statistical Treatment of Geochemical and Environmental Data. Environmental Geology, 39, 
1001-1014. http://dx.doi.org/10.1007/s002549900081

[23] McCoy, J., Davis, J., Camper, J., Kahn, I., and Bharathi, A. (2007) Influence of Rhizome Propagule Size on Yields and Triterpene Glycoside Concentrations in Black Cohosh [Actaea racemosa L. syn Cimicifuga racemosa (L.) Nuttal]. HortScience, 42, 61-64.

[24] Thomas, A., Crawford, R., Rottinghaus, G., Tracy, J., Applequist, W., Schweitzer, B., Havermann, L., Woodbury, S., Miller, J., Ellersieck, M. and Gray, D. (2007) Occurrence of 23-epi-26 Deoxyactein and Cimicifugoside A in Various Black Cohosh Tissues throughout the Growing Season. Hortscience, 42, 535-539.

[25] Dixon, R.A. and Palva, N.L. (1995) Stress-Induced Phenylpropanoid Metabolism. Plant Cell, 7, 1085-1097. http://dx.doi.org/10.1105/tpc.7.7.1085 